\title{
General Approach to the Synthesis of Prochiral Atropisomeric Biaryls
}

\author{
Katarzyna Kielar, Oleg M. Demchuk, and K. Michał Pietrusiewicz \\ Department of Organic Chemistry, Maria Curie-Skłodowska University, 33-Gliniana Street, 20-614 Lublin, Poland \\ Correspondence should be addressed to Oleg M. Demchuk, oleh.demchuk@umcs.lublin.pl
}

Received 27 February 2011; Accepted 24 March 2011

Academic Editors: B. Das and B.-E. Yingyongnarongkul

Copyright (๑) 2011 Katarzyna Kielar et al. This is an open access article distributed under the Creative Commons Attribution License, which permits unrestricted use, distribution, and reproduction in any medium, provided the original work is properly cited.

General approach to the synthesis of prochiral precursors of chiral atropisomeric biaryls based on several complementary methods has been developed. Biaryls were obtained in good to excellent yields depending on their structure and selected method of synthesis. Furthermore, we demonstrate a possibility of utilisation of the obtained compounds possessing 2 or 3 ortho substituents around the aryl-aryl bond in direct and directed arylation reaction leading through transition metal-mediated C-H bond activation to atropisomeric compounds.

\section{Introduction}

Atropisomeric biaryls constitute an important structural element of many natural products, biologically active compounds, and chiral ligands [1]. Despite significant importance of the synthesis of atropisomeric biaryls (even in the racemic form), their syntheses based on the common crosscoupling reaction such as Suzuki-Miyaura (SM), Negishi, Stille, or Hiyama are still rare what could be explained by easily recognised problems associated with creation of sterically hindered multiply ortho-substituted aryl-aryl bonds. Herein, we propose an alternative approach to axially chiral biaryls by selective functionalisation of prochiral substrates, unsubstituted at one or two of the four present ortho positions. Thus, introduction of an additional ortho substituent into the biaryls already bearing 2 or 3 of them eventually restrains free rotation around the single aryl-aryl bond and creates a pair of atropoisomers (Scheme 1). Such functionalisation could be achieved by classical methods if the position of the functionalisation is unambiguously defined by the substitution pattern, or it could be performed in a catalytic manner, mediated by the transition metal (TM) complex and directed by proper functional groups $[2,3]$. Therefore, main impact was made on the synthesis of prochiral precursors of atropisomeric compounds possessing proper functionality for selective introduction of the fourth ortho substituent.
Herein, we would like to present a simple guide for selection of an optimal approach to the synthesis of prochiral biaryls which next could be used in the synthesis of racemic atropisomeric compounds or in their atroposelective synthesis.

\section{Combinatorial Approach}

We have concentrated on the creation of a small library of prochiral biaryls using a combinatorial approach to the SM reactions [4] between several arylboronic acids and arylhalides as well as using other complementary methods. For example, as a result of cross-coupling of nine substrates (both boronic acids and bromoarenes (Table 1)), twenty biaryls could be theoretically obtained.

In the case of the preparation of simple tri-orthosubstituted biaryls, the syntheses of the individual coupling components could be based on the modified known procedures. The majority of aromatic boronic acids could be obtained by the reaction of organometallic compounds such as Grignard reagents [5], organolithium [6], and organozinc [7] ones with trialkyl borates. Some boronic acid derivatives could also be obtained by the direct $\mathrm{C}-\mathrm{H}$ activation protocol with utilisation of diboro- and hydridoboro-aromatics $[8,9]$. These syntheses are suitable for the production of large quantities of boronic acids in a relatively simple manner. For example, desired 2-methoxyphenylboronic acid 
TABLE 1: Aromatic boronic acids and bromoaryls for the cross-coupling reaction.

Arylboronic acids

Total number of products $=20$

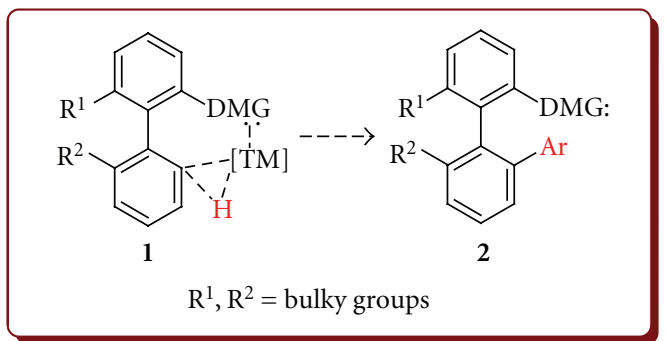

Scheme 1: Formation of chiral atropisomeric compounds with the prochiral precursors.

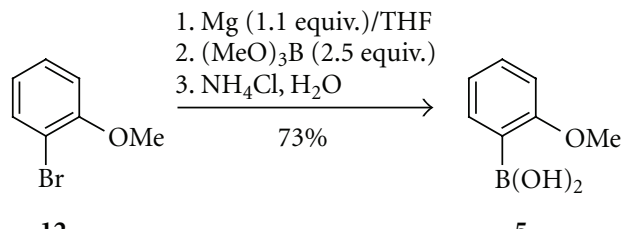

Scheme 2: Synthesis of 2-methoxyphenylboronic acid (5).

(5) was obtained by the approach involving the Grignard reagent in $73 \%$ isolated yield starting from 2-bromoanisole (12) (Scheme 2). Compounds 3, 4, and 6 were prepared in a similar way.

The alternative organolithium approach could be demonstrated by the synthesis of 2-(N,N-diethylcarbamyloxy)phenylboronic acid (7) obtained by tri-isopropyl borate quench of a suitable organolithium reagent formed in the direct ortho lithiation in $81 \%$ isolated yield (Scheme 3). According to the standard procedure [6] the solution of $n$-BuLi was added to DIPA solution in THF at $-5^{\circ} \mathrm{C}$ to form LDA. Then, it was chilled down to $-76^{\circ} \mathrm{C}$, mixed with tri-isopropyl borate and slowly quenched by phenyl diethylcarbamate (15). After that the reaction mixture was allowed to warm up to RT and a base was neutralised with the saturated solution of $\mathrm{NH}_{4} \mathrm{Cl}$, the formed arylboronic acid 7 was extracted with $\mathrm{DCM}$, dried with $\mathrm{MgSO}_{4}$, and eventually purified by flash column chromatography.

In the case of difficulties in purification of some boronic acids, they could be easily converted to the corresponding pinacolborates (available from crude boronic acids in a high yielding reaction with pinacol), which usually undergo rapid chromatographic purification [10]. Importantly, the obtained chromatographically pure pinacolborates (e.g., 17, Scheme 4) could be used in the cross-coupling reaction with the same efficiency as unprotected boronic acids.

Synthesis of aromatic halides or triflates is usually a trivial synthetic task. There is also a large number of these compounds commercially available at reasonable prices. Nevertheless, in some cases, it is more economical to synthesise them by means of one of the many available methodologies. One of the important reactions for obtaining aryl halides is the Sandmeyer reaction [11]. This is a well-known synthesis of aryl halides from aryl diazonium salts. For example, 2-bromo- $\beta$-picoline (10) was rapidly obtained in that reaction from an in situ formed heteroaryl diazonium bromide in $80 \%$ isolated yield (Scheme 5) [12].

Derivatisation of simple aromatic halides can provide a number of diversified substrates for the cross-coupling 


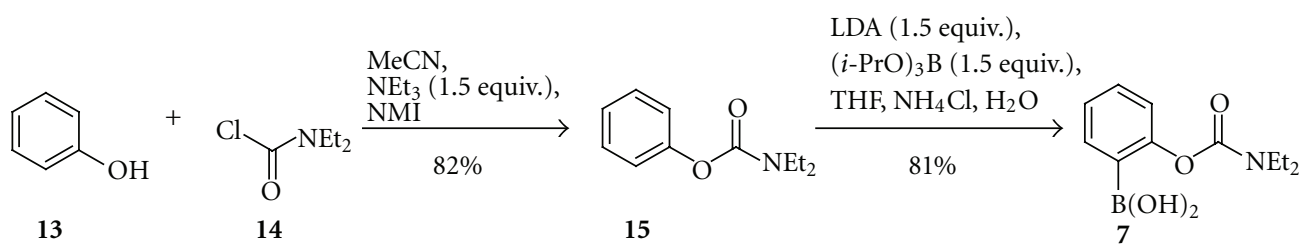

Scheme 3: Synthesis of 2-(N, N-diethylcarbamyloxy)phenylboronic acid (7).

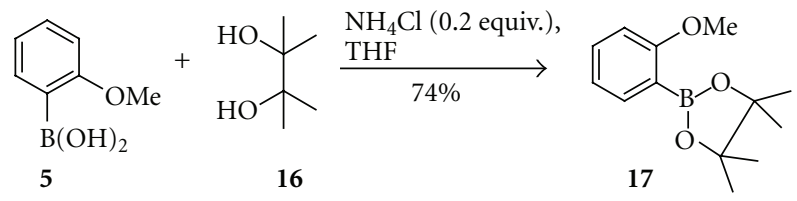

Scheme 4: Synthesis of 2-methoxyphenylpinacolborate (17).

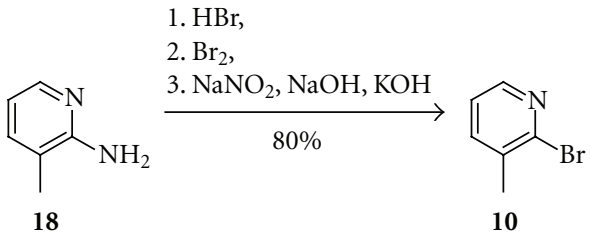

Scheme 5: Synthesis of 2-bromo- $\beta$-picoline (10).

reactions. For example, the reactions of 2-bromophenol (19) with simple derivatisation agents such as diethylcarbamoyl chloride (20) or pivaloyl chloride (21) ran in DMF at $0^{\circ} \mathrm{C}$ and catalysed by $N$-methylimidazole (NMI) or DMAP lead to 2-bromophenyl diethylcarbamate (11) and 2-bromophenyl pivalate (9) in $86 \%$ and $72 \%$ yields, respectively (Scheme 6).

Obtained halides 9, 10, 11, and 19 were used as precursors of prochiral biaryls possessing in the ortho position to aryl-aryl bond a functional group potentially useful for coordination of transition metals. Therefore, the desired activation of $\mathrm{C}-\mathrm{H}$ bond and directing effects of the planned transition metal-catalysed reactions at a remote biaryl position as delineated in Scheme 1 could be expected.

\section{Synthesis of Prochiral Biaryls}

3.1. Synthesis by the Suzuki Cross-Coupling Reaction. Probably the simplest way to biaryls is via SM coupling of boronic acid with aryl halides. The major limitation of the SM coupling reactions is difficulty in the creation of sterically hindered biaryls possessing more than two ortho substituents [13]. At the same time the synthesis of prochiral (doubly or triply ortho-substituted biaryls) can be usually performed in high yields. One of the model prochiral biaryls, 3-methyl-2(4-methylphenyl)pyridine (25), was obtained in $48 \%$ yield in the reaction of 4-methylphenylboronic acid (3) with 2bromo- $\beta$-picoline (10) (Scheme 7). This biaryl precursor could be used in the synthesis of chiral atropisomeric compounds $\mathbf{2 6}$ in the reaction mediated by TM complexes directed by a lone electron pair of nitrogen and run through the $\mathrm{CH}$ activation step.
The application of pinacoloborates in the SM reaction is well recognised and is frequently utilized in cases where the corresponding boronic acids are difficult to purify. Nevertheless, the direct comparison of efficiency of utilising in coupling reactions boronic acids and the corresponding boranates is very rare. The synthesis of 3-methyl-2-(2'methoxyphenyl)pyridine (27) shown in Scheme 8 provides such an example. The 2-bromo- $\beta$-picoline (10) undergoes the SM reaction with 2-methoxyphenylboronic acid (5) or corresponding pinacol ester (17) under palladium-catalysed conditions with the yields depending on conditions and substrates used. In order to optimise the reaction conditions several different solvents, bases, catalysts, and additives were tested (Table 2).

The best yield (Table 2, entry 8) was obtained when 2-methoxyphenylboronic (5) acid was utilised in DMF/ methanol mixture with tetrakis(triphenylphosphine)palla$\operatorname{dium}(0)$ as the catalyst. Of many bases used, only potassium phosphate monohydrate secured good yields. The data collected in Table 2 confirmed also a crucial role of water and a strong inorganic base of low nucleophilicity required to achieve reasonable yield in SM reaction.

As mentioned previously, obtained prochiral biaryl compound 27 could be used in the synthesis of atropisomeric compound 28 by substitution of hydrogen atom in the second ortho position with any bulky group (Scheme 8).

Similarly, prochiral 3-methyl-2-(1-naphthyl)pyridine (29) was prepared by coupling of 1-naphtylboronic acid (6) with 2 -bromo- $\beta$-picoline (10) in $74 \%$ yield (Scheme 9 ) and could be used for the synthesis of atropisomeric compound 30 by substitution of hydrogen in position 2 or 8 of the naphthalene ring directed by a lone electron pair of nitrogen. 
TABLE 2: Optimisation of the reaction conditions of synthesis of 3-methyl-2-(2'-methoxyphenyl)pyridine (27).

\begin{tabular}{|c|c|c|c|c|c|}
\hline Entry & Substrate & Solvent & Base & Catalyst & Yield [\%] ${ }^{\mathrm{a}}$ \\
\hline 1 & 17 & Toluene/ethanol & $\mathrm{Na}_{2} \mathrm{CO}_{4}$ (aq.) & {$\left[\mathrm{Pd}\left(\mathrm{PPh}_{3}\right)_{4}\right]$} & trace \\
\hline 2 & 5 & DMF (anh.) & $\mathrm{K}_{3} \mathrm{PO}_{4}$ (anh.) & {$\left[\mathrm{Pd}\left(\mathrm{PPh}_{3}\right)_{4}\right]$} & 46 \\
\hline 3 & 5 & DMF (anh.) & $\mathrm{K}_{3} \mathrm{PO}_{4} \cdot \mathrm{H}_{2} \mathrm{O}$ & {$\left[\mathrm{Pd}\left(\mathrm{PPh}_{3}\right)_{4}\right]$} & 49 \\
\hline 4 & 5 & DMF & $\mathrm{K}_{3} \mathrm{PO}_{4} \cdot \mathrm{H}_{2} \mathrm{O}$ & {$\left[\mathrm{Pd}\left(\mathrm{PPh}_{3}\right)_{4}\right]$} & 57 \\
\hline 5 & 5 & DMF & $\mathrm{K}_{3} \mathrm{PO}_{4} \cdot \mathrm{H}_{2} \mathrm{O}$ & $\mathrm{Ph}_{3} \mathrm{P}, \mathrm{Pd}(\mathrm{AcO})_{2}$ & 54 \\
\hline 6 & 5 & $\mathrm{MeOH}$ & $\mathrm{K}_{3} \mathrm{PO}_{4} \cdot \mathrm{H}_{2} \mathrm{O}$ & {$\left[\mathrm{Pd}\left(\mathrm{PPh}_{3}\right)_{4}\right]$} & $42^{\mathrm{b}}$ \\
\hline 7 & 17 & $\mathrm{MeOH}$ & $\mathrm{K}_{3} \mathrm{PO}_{4} \cdot \mathrm{H}_{2} \mathrm{O}$ & {$\left[\mathrm{Pd}\left(\mathrm{PPh}_{3}\right)_{4}\right]$} & 59 \\
\hline 8 & 5 & $\mathrm{DMF} / \mathrm{MeOH}$ & $\mathrm{K}_{3} \mathrm{PO}_{4} \cdot \mathrm{H}_{2} \mathrm{O}$ & {$\left[\mathrm{Pd}\left(\mathrm{PPh}_{3}\right)_{4}\right]$} & 66 \\
\hline 9 & 5 & $\mathrm{MeOH} / \mathrm{H}_{2} \mathrm{O}$ & $\mathrm{AgOAc}$ & {$\left[\mathrm{Pd}\left(\mathrm{PPh}_{3}\right)_{4}\right]$} & 0 \\
\hline 10 & 5 & $\mathrm{MeOH} / \mathrm{H}_{2} \mathrm{O}$ & $\mathrm{Ag}_{2} \mathrm{CO}_{3}$ & {$\left[\mathrm{Pd}\left(\mathrm{PPh}_{3}\right)_{4}\right]$} & 0 \\
\hline
\end{tabular}

${ }^{\mathrm{a}}$ Reactions were carried out under argon atmosphere, under gentle reflux. ${ }^{\mathrm{b}}$ Reaction run at $130^{\circ} \mathrm{C}$ in sealed vessel.

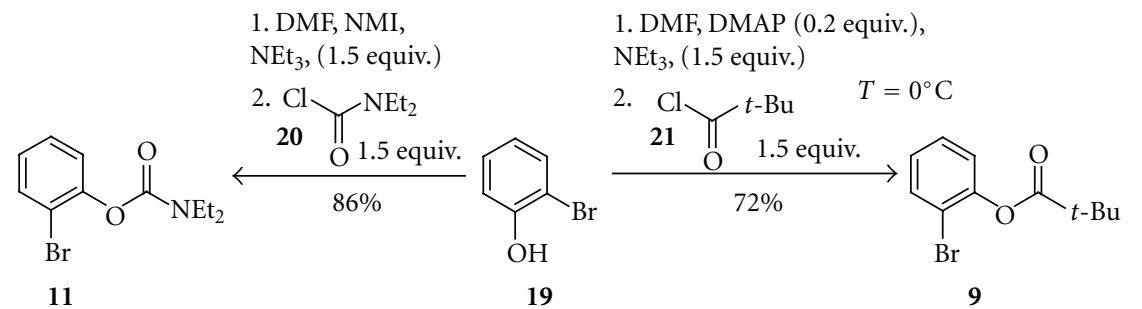

Scheme 6: Synthesis of 2-bromophenyl diethylcarbamate (11) and 2-bromophenyl pivalate (9).

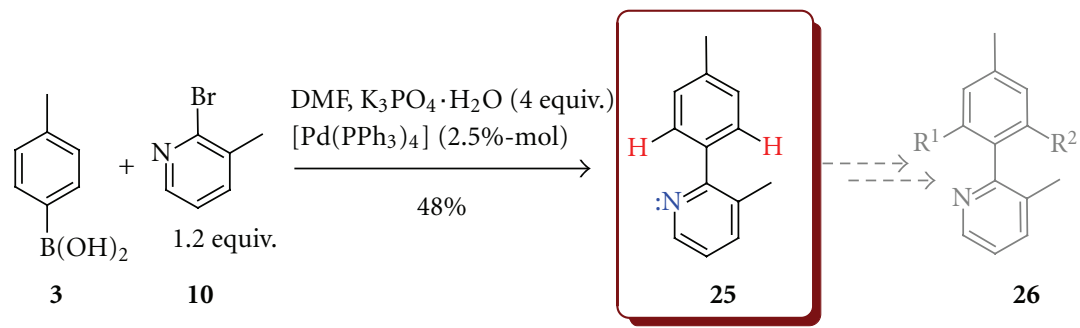

SCHeme 7: Model synthesis of 3-methyl-2-(4-methylphenyl)pyridine (25).

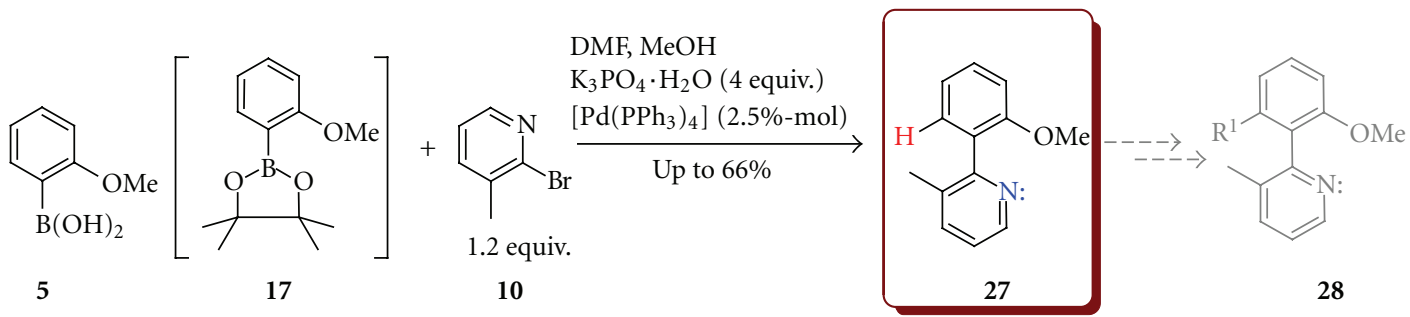

Scheme 8: Synthesis of 3-methyl-2-(2'-methoxyphenyl)pyridine (27).

Based on naphthylphenyl core biaryl 31 (2-(naphthalen$1-y l)$ phenyl diethylcarbamate), possessing a directing metalation group (DMG), different from nitrogen, was obtained under similar reaction conditions by coupling of 1naphthylboronic acid (6) and 2-bromophenyl diethylcarbamate (11) in 74\% yield. In this case, diethylcarbamate is the group-directing substitution of hydrogen in the position 2 or 8 of naphthalene ring (Scheme 10).
3.2. Synthesis by Functionalisation of Available Substrates. In many cases there is no reason to create biaryls by coupling of two monoaryl compounds because of availability of easy to functionalise biaryls. For example, commercially available 2,2' -biphenol (33) could be used as a substrate for synthesis of chiral 3,3' -disubstituted biphenol derivatives. Not only 33 but also its derivatives with the DMG groups such as carbamates could be used for the synthesis of 


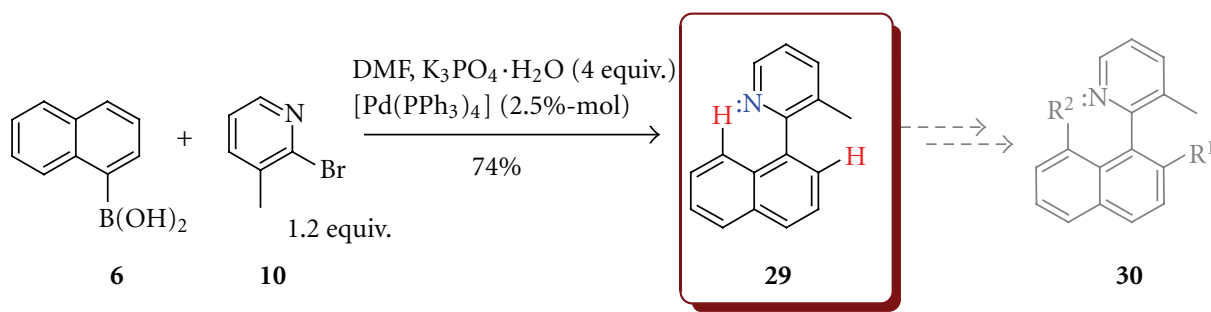

Scheme 9: Synthesis 3-methyl-2-(1-naphthyl)pyridine (29).

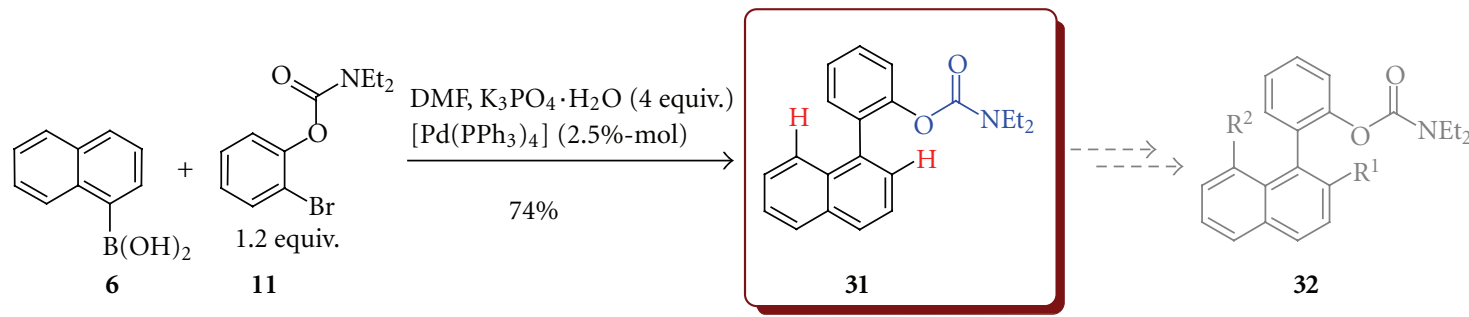

Scheme 10: Synthesis of 2-(1-naphthyl)phenyl diethylcarbamate (31).

atropisomeric biaryls (Scheme 12). Some DMG substituted derivatives were rapidly prepared from 33 . Thus, the reaction of $2,2^{\prime}$-biphenol with diethylcarbamoyl chloride (10) led to biphenyl-2,2' -diyl bis(diethylcarbamate) (34) in $67 \%$ yield. 2' -Hydroxybiphenyl-2-yl diethylcarbamate (35), which could be used as another prochiral substrate, was also isolated as a side product of this reaction in $10 \%$ yield only (Scheme 11).

Mixed O-pivaloyl,O-carbamoylobiphenol (39) was obtained in reaction of 35 with the stoichiometric amount of 2,2-dimethylpropanoyl chloride (21) in $82 \%$ yield. The obtained product 39 could be used as a precursor of the synthesis of chiral biaryls in the reaction directed by either pivaloyl or carbamoyl function (Scheme 12).

3.3. Synthesis by the Meyers Reaction. A less popular but still powerful method of aryl-aryl bond formation by Meyers reaction $[14,15]$ could be successfully used when the substitution pattern does not allow to achieve acceptable yield in the TM-mediated cross couplings. For example, for oxazole and oxazoline ortho-substituted halogenoarenes as well as boronic acids, the TM catalysed couplings proved to be difficult because of strong interaction of those heterocyclic substituents with the catalysts. Desired oxazole and oxazoline ortho-substituted biaryls could be however accessible by the Meyers reaction utilising the ortho-methoxy-substituted aryloxazolines (and some other ortho-methoxy-substituted aromatics [15]) in good yields (Scheme 13). For example, 2-(2-methoxyphenyl)4,4-dimethyl-4,5-dihydro-1,3-oxazole (8) undergoes the ipso nucleophilic substitution reaction when treated with 2methoxyphenylmagnesium bromide (41) and forms prochiral biaryl 42 in $94 \%$ yield. Obtained products 42 may be used for the synthesis of chiral compound $\mathbf{4 3}$ by substitution of hydrogen with the bulky group possible in the $\mathrm{C}-\mathrm{H}$-activated reaction directed by oxazoline (Scheme 13).

\section{Application of Prochiral Compounds in the Synthesis of Atropisomeric Biaryls}

To demonstrate a possibility of transformation of prochiral biaryl into the atropisomeric ones, we carried out direct arylation reaction directed by a lone electron pair of nitrogen atom. Thus, the reaction of 3-methyl-2-(pmethylphenyl)pyridine (25) with 4-bromoanisole (44) led to a mixture of mono- and disubstituted products 45 , and 46 (Scheme 14).

Obtained monosubstituted product 45, could be used in the next arylation synthesis with different halogenoarenes (other than $4-\mathrm{MeOC}_{6} \mathrm{H}_{4}$ ) to accomplish doubly ortho arylated biaryl. High yield in the monosubstitution reaction was obtained when $\left[\mathrm{RuCl}_{2} \text { (p-cymene) }\right]_{2}$ was utilised as a catalyst precursor with no phosphorus ligands added (Table 3, entry 7 ). When tris(pentafluorophenyl)phosphine was used in combination with $\left[\mathrm{RuCl}_{2} \text { (p-cymene) }\right]_{2}$ to form a catalyst the formation of disubstituted product 46 in 28\% yield was observed (Table 3, entry 6). The most suitable solvent was 1-methyl-2-pyrrolidone (NMP).

The proposed protocol offers an alternative to the traditional aryl-aryl coupling approach to atropisomeric biaryls based on direct and directed by certain DMGs arylation running through the $\mathrm{C}-\mathrm{H}$ activation reaction step. Of the DMGs promoting aromatic $\mathrm{C}-\mathrm{H}$ activation reactions, perhaps the most powerful are $\mathrm{sp}^{2}$-hybridised nitrogen, carbonyl group, secondary amine, and, rarely, aromatic hydroxyl group. Nevertheless, other functionalities such as nitro group, carbamate, and carboxylate groups as well as those possessing a lone electron pair at a proximal heteroatom, could play a role of a DMG in transition metal mediated $\mathrm{C}-\mathrm{H}$ activation reactions $[16,17]$. The extension of library of DMGs on new functional groups will create an additional opportunity for the synthesis of atropisomeric biaryls. 


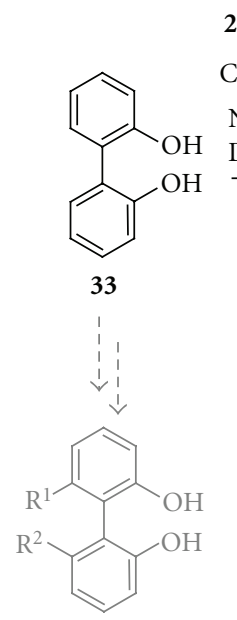

36
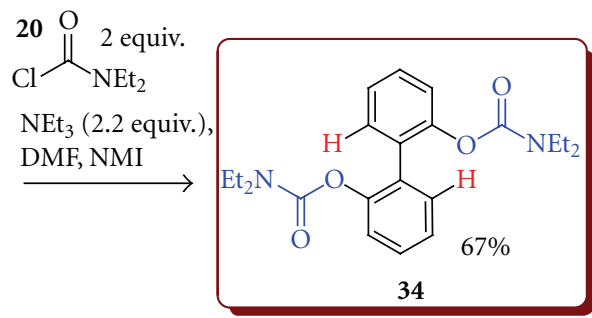

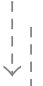

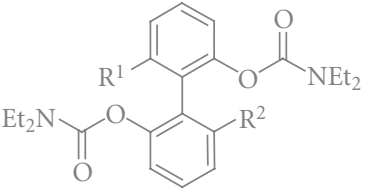

37
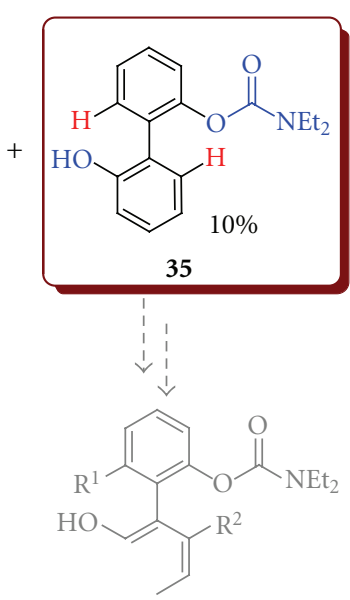

38

Scheme 11: Synthesis of biphenyl-2,2' -diyl bis(diethylcarbamate) (34) and 2'-hydroxybiphenyl-2-yl diethylcarbamate (35).

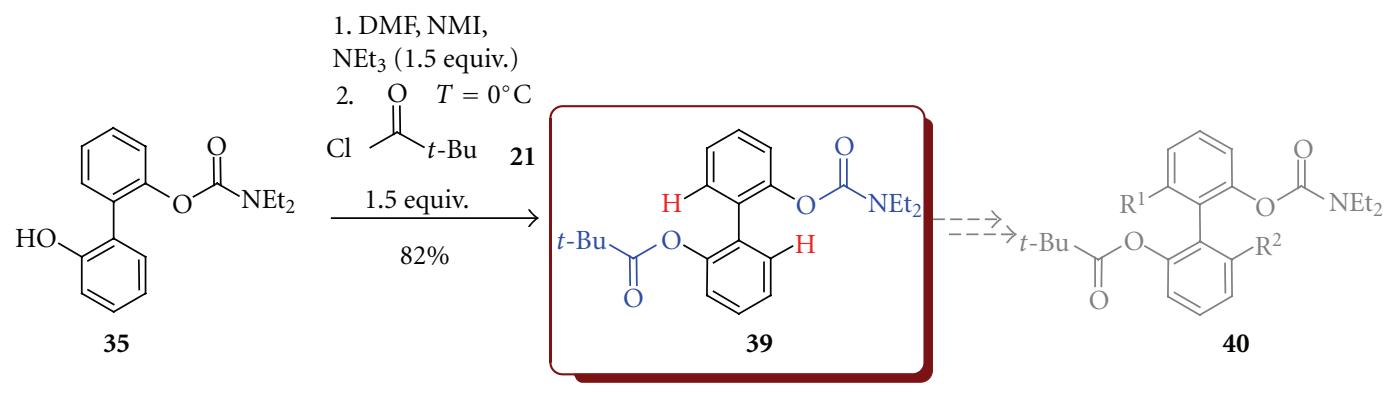

Scheme 12: Synthesis of $2^{\prime}$ - pivaloyloxy-2' -N,N-diethylcarbomoyloxybiphenyl (39).
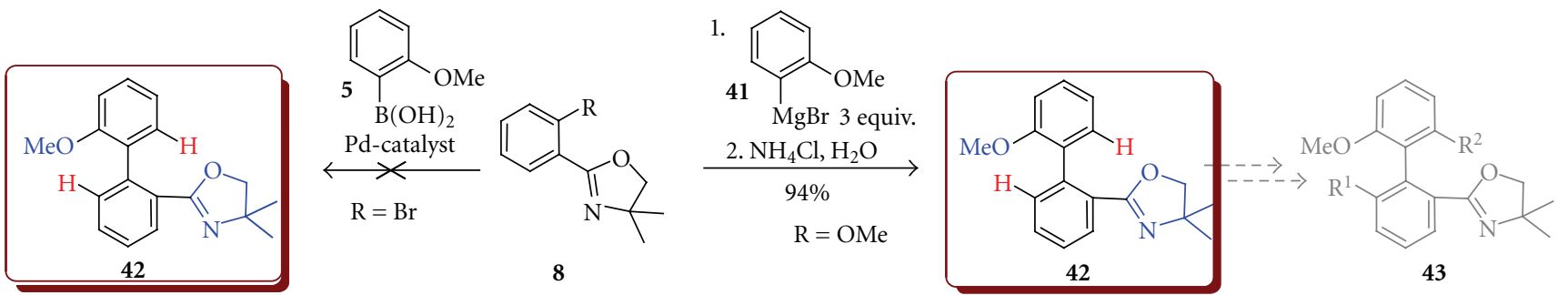

Scheme 13: Synthesis of 2-(2'-methoxybiphenyl-2-yl)-4,4-dimethyl-4,5-dihydro-1,3-oxazole (42).<smiles>Cc1ccc(-c2ncccc2C)cc1</smiles>

25<smiles>COc1ccc(Br)cc1</smiles>

44
Precatalyst, ligand, solvent, base<smiles>COc1ccc(-c2cc(C)ccc2-c2ncccc2C)cc1</smiles>
45<smiles>COc1ccc(-c2cc(C)cc(-c3ccc(OC)cc3)c2-c2ncccc2C)cc1</smiles>

46

Scheme 14: Synthesis of 4-methoxy-5'-methyl-1,1' $: 2^{\prime}, 1^{\prime \prime}$-terphenyl (45) and 4-methoxy-3'-(4-methoxyphenyl)-5'-methyl-1, $1^{\prime}: 2^{\prime}, 1^{\prime \prime}$-terphenyl (46). 
TABLE 3: Optimisation of direct arylation reaction.

\begin{tabular}{|c|c|c|c|c|c|c|}
\hline Entry & Base & Catalyst & Ligand & $45[\%]$ & $46[\%]$ & Conversion $[\%]$ \\
\hline \multirow{2}{*}{1} & $\mathrm{Cs}_{2} \mathrm{CO}_{3}$ & \multirow{2}{*}[\mathrm{RhCl}(\operatorname{cod})]{$_{2}$} & \multirow{2}{*}{ none } & \multirow{2}{*}{2} & \multirow{2}{*}{3} & \multirow{2}{*}{5} \\
\hline & $\mathrm{Ag}_{2} \mathrm{CO}_{3}$ & & & & & \\
\hline 2 & $\mathrm{Cs}_{2} \mathrm{CO}_{3}$ & {$[\mathrm{RhCl}(\operatorname{cod})]_{2}$} & none & $32(36)^{\mathrm{b}}$ & 2 & 34 \\
\hline 3 & $\mathrm{Cs}_{2} \mathrm{CO}_{3}$ & {$[\mathrm{RhCl}(\operatorname{cod})]_{2}$} & $\mathrm{PPh}_{3}$ & $4^{\mathrm{a}}$ & $3^{\mathrm{a}}$ & $7^{\mathrm{a}}$ \\
\hline 4 & $\mathrm{Cs}_{2} \mathrm{CO}_{3}$ & {$[\mathrm{RhCl}(\mathrm{cod})]_{2}$} & S-Phos & $72(64)^{b}$ & 4 & 76 \\
\hline 5 & $\mathrm{Cs}_{2} \mathrm{CO}_{3}$ & {$\left[\mathrm{RuCl}_{2}(\mathrm{p} \text {-cymene })\right]_{2}$} & $\mathrm{PPh}_{3}$ & $1^{\mathrm{a}}$ & $1^{\mathrm{a}}$ & $2^{\mathrm{a}}$ \\
\hline 6 & $\mathrm{Cs}_{2} \mathrm{CO}_{3}$ & {$\left[\mathrm{RuCl}_{2}(\mathrm{p} \text {-cymene })\right]_{2}$} & tris(pentafluorophenyl)-phosphine & 28 & 31 & 59 \\
\hline 7 & $\mathrm{Cs}_{2} \mathrm{CO}_{3}$ & {$\left[\mathrm{RuCl}_{2}(\mathrm{p} \text {-cymene })\right]_{2}$} & none & 71 & 13 & 84 \\
\hline 8 & $\mathrm{Cs}_{2} \mathrm{CO}_{3}$ & {$\left[\mathrm{RuCl}_{2}(\mathrm{p} \text {-cymene })\right]_{2}$} & tris (2,4,6-trimethoxy-phenyl)phosphine & 24 & 18 & 42 \\
\hline 9 & $\mathrm{Cs}_{2} \mathrm{CO}_{3}$ & {$\left[\mathrm{RuCl}_{2}(\mathrm{p} \text {-cymene })\right]_{2}$} & dppe & 29 & 7 & 36 \\
\hline 10 & $\mathrm{~K}_{2} \mathrm{CO}_{3}$ & {$\left[\mathrm{RuCl}_{2}(\mathrm{p} \text {-cymene })\right]_{2}$} & S-Phos & 54 & 33 & 87 \\
\hline
\end{tabular}

The reactions were carried out under argon atmosphere, in NMP, at $160^{\circ} \mathrm{C}$, for 24 hours, HPLC yields, ${ }^{\text {a } 2}$ equiv. of compound 44 were used in the reaction. ${ }^{\mathrm{b}}$ The isolated yields are given in the parentheses.

\section{Conclusion}

In summary, we have demonstrated a general approach to the synthesis of prochiral biaryls by several complementary methods. The selection of the method was based on the analysis of the availability of starting materials and desirable substitution pattern of the target products. The assumption that easily available prochiral biaryls could be the perspective substrates in the synthesis of atropoismer compounds was confirmed in model direct and directed by the nitrogen lone electron pair transition metal mediated arylation of 2 -arylopirydines ran though the $\mathrm{CH}$ activation reaction step. The results of the asymmetric direct arylation will be reported separately in due time.

\section{Experimental}

6.1. General. All Suzuki coupling reactions were carried out under argon atmosphere using oven-dried glassware and the dry solvent. The reactions were monitored on TLC. The products were purified by distillation or flash column chromatography (Merck silica gel 60 (230-400 mesh)). ${ }^{1}$ HNMR: spectra were recorded on Bruker AVANCE 300 in $\mathrm{CDCl}_{3}$; chemical shifts are given in ppm relative to TMS, coupling constants $(J)$ in Hz. attenuated total reflection IR spectra were recorded on FTIR Nicolet 8700 A spectrometer and measured in $\mathrm{cm}^{-1}$. The HRMS (ESI) measurements were performed on Shimadzu LCMS-IT-TOF instrument. HPLC study was performed on a Merck reversed-phase column: $250 \times 4 \mathrm{~mm}, 5 \mu \mathrm{m}$, eluted by methanol/water. All melting points were measured using the Boëtius apparatus and are not corrected. All commercially available substrates were used as received, and all known self-made substrates were examined by comparison with authentic commercial samples.

4-Methylphenylboronic Acid (4). A dried $500 \mathrm{~mL}$ flask equipped with a magnetic stirrer, dropping funnel, and reflux condenser was charged with magnesium turnings (1.1 equiv., $80.6 \mathrm{mmol}$ ), next, flask was argonated by vacuum/argon triple exchange and a solution of a few crystal of iodine in $10 \mathrm{~mL}$ THF was added to activate of the magnesium. Next a solution of 4-bromotoluene (1 equiv., $73 \mathrm{mmol}$ ) in dry THF $(100 \mathrm{~mL})$ was added dropwise for a period of 1 hour while the reaction mixture was stirred and heated to maintain a gentle reflux. After the additional $1 \mathrm{~h}$ refluxing solution was cooled down to $-78^{\circ} \mathrm{C}$ and trimethylborate (22 mL, $183 \mathrm{mmol}, 2.5$ equiv.) in dry THF $(85 \mathrm{~mL})$ was slowly added. The mixture was gradually warmed to room temperature then stirred overnight. Reaction was quenched with saturated aqueous solution of $\mathrm{NH}_{4} \mathrm{Cl}(70 \mathrm{~mL})$ and then THF was removed under reduced pressure. The precipitated crystalline $\mathbf{4}$ was filtered, washed with cold water and next few times with ether diethyl, dried under vacuum. Yield $6.13 \mathrm{~g}(61 \%), \mathrm{mp} 242-245^{\circ} \mathrm{C}$, (lit. [18] 256-263 ${ }^{\circ} \mathrm{C}$ ).

4-Methoxyphenylboronic acid (3) was prepared in a similar way as 4. Yield $17.9 \mathrm{~g}, 56 \%, \mathrm{mp} 202^{\circ} \mathrm{C}$, (Lit. [19] 202$\left.204^{\circ} \mathrm{C}\right)$.

2-Methoxyphenylboronic acid (5) was prepared in a similar way as 4. Yield $17.6 \mathrm{~g}, 73 \%, \mathrm{mp} 99^{\circ} \mathrm{C}$, (Lit. [20] $105^{\circ} \mathrm{C}$ ).

1-Naphtylboronic acid (6) was prepared in a similar way as 4. Yield $21.1 \mathrm{~g}, 85 \%$, mp $217-219^{\circ} \mathrm{C}$, (Lit. [21] 202-203 ${ }^{\circ} \mathrm{C}$ ).

2-(N,N-diethylcarbamoyloxy)phenylboronic acid (7) was obtained in two steps.

(1) A $100 \mathrm{~mL}$ flask equipped with a magnetic stirrer was charged with phenol ( $53.2 \mathrm{mmol}, 1$ equiv.), $50 \mathrm{~mL}$ acetonitrile, $4.5 \mathrm{~mL} \mathrm{~N}$-methylimidazole, triethylamine (79.8 mmol, 1.5 equiv.), and diethylcarbamoyl chloride (14) (79.8 mmol, 1.5 equiv.). The flask was closed with a tight PTFE stopper and heated at $100^{\circ} \mathrm{C}$ for $24 \mathrm{~h}$. After that time, the reaction solution was cooled down to room temperature and the solvents were removed under reduced pressure. $100 \mathrm{~mL}$ water was added to a residue, and product was extracted with diethyl ether $(90 \mathrm{~mL})$, washed with water $(80 \mathrm{~mL})$ and $5 \%$ aq. $\mathrm{NaOH}(30 \mathrm{~mL})$. 
The organic phase was separated and dried with $\mathrm{MgSO}_{4}$. Solvent was evaporated in vacuum and the remaining residue was distilled under the reduced pressure of $1 \mathrm{mmHg}$, the product was collected in fraction at about $100^{\circ} \mathrm{C}$. Yield $8.4 \mathrm{~g}(82 \%$ yield $) .{ }^{1} \mathrm{H}$ $\operatorname{NMR}\left(300.33 \mathrm{MHz}, \mathrm{CDCl}_{3}\right): \delta=1.23-1.27(\mathrm{~m}, 6 \mathrm{H})$ 3.40-3.47 (m, 4H) 7.12-7.23 (m, 3H) 7.34-7.40 (m, 2H). (Lit. [22]).

(2) A $100 \mathrm{~mL}$ flask equipped with a magnetic stirrer was argonated by vacuum/argon triple exchange and charged with DIPA (10.2 mmol, 1.5 equiv.) and $30 \mathrm{~mL}$ THF next cooled down to $-30^{\circ} \mathrm{C}$ followed by $1.6 \mathrm{M}$ solution of $n$-BuLi in hexane $(10.2 \mathrm{mmol}$, 1.5 equiv.) was slowly added. The LDA solution was stirred for $30 \mathrm{~min}$ at $-30^{\circ} \mathrm{C}$ and then cooled down to $-78^{\circ} \mathrm{C}$. A solution of tri-isopropyl borate (10.2 mmol, 1.5 equiv.) in $10 \mathrm{~mL}$ THF was injected to the reaction mixture followed by a solution of $\mathbf{1 5}$ ( $6.8 \mathrm{mmol}, 1$ equiv.) in $10 \mathrm{~mL}$ THF was slowly added. All the time, the reaction temperature was maintain between $-78^{\circ} \mathrm{C}$ and $-70^{\circ} \mathrm{C}$. After addition, the reaction mixture was allowed to warm to room temperature and was quenched with saturated aqueous solution of $\mathrm{NH}_{4} \mathrm{Cl}(60 \mathrm{~mL})$. THF was removed under reduced pressure, and the product was extracted from residue with dichloromethane $(60 \mathrm{~mL})$. The organic phase was removed, washed with diluted aq. $\mathrm{NaHCO}_{3}(3 \times 20 \mathrm{~mL})$, next with water $(2 \times 20 \mathrm{~mL})$ and dried with $\mathrm{MgSO}_{4}$. Solvent was evaporated in vacuum, and the remaining pure product 7 was collected. Yield $3.96 \mathrm{~g}\left(81 \%, \mathrm{mp} 162-165^{\circ} \mathrm{C}\right) .{ }^{1} \mathrm{H}$ $\operatorname{NMR}\left(300.33 \mathrm{MHz}, \mathrm{CDCl}_{3}\right): \delta=1.04-1.13(\mathrm{~m}, 6 \mathrm{H})$ $3.22-3.32(\mathrm{~m}, 4 \mathrm{H}) 7.02(\mathrm{~d}, J=8.05,1 \mathrm{H}) 7.18-7.23$ $(\mathrm{m}, 1 \mathrm{H}) 7.33-7.39(\mathrm{~m}, 1 \mathrm{H}) 7.85-7.88(\mathrm{~m}, 1 \mathrm{H}),{ }^{13} \mathrm{C}$ $\operatorname{NMR}\left(62.90 \mathrm{MHz}, \mathrm{CDCl}_{3}\right): \delta=11.45,12.03,40.09$, $40.52,74.84,75.34,75.86,117.54,123.20,128.44$, 133.60, 153.62 (Lit. [23]).

2-Methoxyphenylpinacolborate (17). A $50 \mathrm{~mL}$ flask equipped with a magnetic stirrer was charged with 2-methoxyphenylboronic acid (5) (13.1 mmol, 1 equiv.), $30 \mathrm{~mL}$ of THF, pinacol (16) (15.8 mmol, 1.2 equiv.), and $\mathrm{NH}_{4} \mathrm{Cl}(2.6 \mathrm{mmol}$, 0.2 equiv.) then heated at $40^{\circ} \mathrm{C}$ for 24 hours. After that time, THF was removed under reduced pressure and product was crystallised from petroleum ether. Yield $2.31 \mathrm{~g}(73 \%), \mathrm{mp}$ $80-82^{\circ} \mathrm{C}$ (Lit. $\left.[10,24] 80-81^{\circ} \mathrm{C}\right)$.

2-Bromo- $\beta$-picoline (10). A $100 \mathrm{~mL}$ flask equipped with a magnetic stirrer and thermometer was charged with $40 \%$ aqueous solution of $\operatorname{HBr}(39.5 \mathrm{~mL})$, cooled down to $-10^{\circ} \mathrm{C}$, and 2 -amino- $\beta$-picoline (18) $(80 \mathrm{mmol})$ was slowly added. The temperature was kept below $0^{\circ} \mathrm{C}$ while $\mathrm{Br}_{2}(0.23 \mathrm{mmol})$ was added over a period of $2 \mathrm{~h}$. After that, a solution of $\mathrm{NaNO}_{2}(0.2 \mathrm{~mol})$ in $\mathrm{H}_{2} \mathrm{O}(20 \mathrm{~mL})$ was slowly added at the same temperature, and the mixture was stirred for next 30 minute. The mixture was gradually warmed to room temperature and was stirred 1 hour more. After that solution of $\mathrm{NaOH}(0.75 \mathrm{~mol})$ in $\mathrm{H}_{2} \mathrm{O}(30 \mathrm{~mL})$ and solid $\mathrm{KOH}$
( $90 \mathrm{mmol}$ ) were added. After 1 hour of stirring products were extracted with diethyl ether. The organic phase was separated and dried with $\mathrm{MgSO}_{4}$. Solvent was evaporated in vacuum and the remaining residue was distilled to give $8.16 \mathrm{~g}(80 \%)$ of $10 . \mathrm{Bp} 69^{\circ} \mathrm{C}$ at $12 \mathrm{mmHg}$ (Lit. [8] $76-77^{\circ} \mathrm{C}$ at $7 \mathrm{mmHg}$ ).

2-Bromophenyl Pivalate (9). A $100 \mathrm{~mL}$ flask equipped with a magnetic stirrer charged with 2-bromophenol (19) (11.6 mmol, 1 equiv.), $20 \mathrm{~mL}$ dichloromethane, $1.1 \mathrm{~mL} \mathrm{~N}$ methylimidazole, and triethylamine $(1.76 \mathrm{~g}, 17.4 \mathrm{mmol}, 1.5$ equiv.) was cooled down to $0^{\circ} \mathrm{C}$, and pivaloyl chloride (21) (17.4 mmol, 1.5 equiv.) was added. The mixture next was stirred for 2 hours at room temperature, the solvents were removed under reduced pressure, and a residue was diluted with water. The product was extracted with diethyl ether and washed with aqueous $1 \mathrm{M} \mathrm{HCl}$, saturated solution of $\mathrm{NaHCO}_{3}$ and water again. The organic phase was separated and dried with $\mathrm{MgSO}_{4}$. Solvent was evaporated in vacuum and the remaining residue was distilled to give $2.73 \mathrm{~g}$ (90\%) of 9. Bp $115^{\circ} \mathrm{C}$ at $1 \mathrm{mmHg} .{ }^{1} \mathrm{H}$ NMR $(300.33 \mathrm{MHz}$, $\left.\mathrm{CDCl}_{3}\right): \delta=1.43(\mathrm{sc}, 9 \mathrm{H}) 7.10-7.15(\mathrm{~m}, 2 \mathrm{H}) 7.28-7.37(\mathrm{~m}$, 1H) $7.60-7.63(\mathrm{~m}, 1 \mathrm{H})$. (Lit [25]).

2-Bromophenyl diethylcarbamate (11) was prepared in a similar way as 9, but DMF was used as a solvent instead of DCM. Yield $1.26 \mathrm{~g}(86 \%)$, bp $125^{\circ} \mathrm{C}$ at $1 \mathrm{mmHg}$. (Lit. [26]).

3-Methyl-2-(4-methylphenyl)pyridine (25). A $50 \mathrm{~mL}$ flask equipped with a magnetic stirrer was argonated by vacuum/ argon triple exchange and charged with 4-methoxyphenylboronic acid (3) (21.8 mmol, 2 equiv.), 2-bromo- $\beta$-picoline (10) $\left(10.9 \mathrm{mmol}, 1\right.$ equiv.), $\mathrm{K}_{3} \mathrm{PO}_{4} \cdot \mathrm{H}_{2} \mathrm{O}(43.6 \mathrm{mmol}), 30 \mathrm{~mL}$ DMF, and $\left[\mathrm{Pd}\left(\mathrm{PPh}_{3}\right)_{4}\right](0.27 \mathrm{mmol})$. The flask was closed with a tight PTFE stopper and heated at $130^{\circ} \mathrm{C}$ for $24 \mathrm{~h}$. The reaction mixture was allowed to cool down to room temperature and DMF was removed under reduced pressure. The product was extracted with diethyl ether and washed with water. The organic phase was separated and dried with $\mathrm{MgSO}_{4}$. Solvent was evaporated in vacuum and the remaining residue was purified by column chromatography on silica gel using hexane/isopropanol (9/1) as an eluent. Yield $1 \mathrm{~g}(48 \%) .{ }^{1} \mathrm{H}$ NMR $\left(300.33 \mathrm{MHz}, \mathrm{CDCl}_{3}\right): \delta=2.38$ $(\mathrm{sc}, 3 \mathrm{H}) 2.42(\mathrm{sc}, 3 \mathrm{H}) 7.16(\mathrm{q}, J=4.76,2.93 \mathrm{~Hz}, J=4.76 \mathrm{~Hz}$, $1 \mathrm{H}) 7.45(\mathrm{~d}, J=8.05 \mathrm{~Hz}, 2 \mathrm{H}) 7.28(\mathrm{~d}, J=7.68 \mathrm{~Hz}, 2 \mathrm{H}) 7.58$ (d, $J=7.50 \mathrm{~Hz}, 1 \mathrm{H}) 8.54$ (d, $J=4.76 \mathrm{~Hz}, 1 \mathrm{H})$. (Lit. [27]).

3-Methyl-2-(2-methoxyphenyl)pyridine (27) was prepared in a similar way as 25 . Yield $435 \mathrm{mg}(66 \%) .{ }^{1} \mathrm{H}$ NMR $\left(300.33 \mathrm{MHz}, \mathrm{CDCl}_{3}\right): \delta=2.18(\mathrm{sc}, 3 \mathrm{H}) 3.78(\mathrm{sc}, 3 \mathrm{H}) 6.98$ $(\mathrm{d}, J=8,2 \mathrm{~Hz}, 1 \mathrm{H}) 7.06(\mathrm{t}, J=7.5,8.5 \mathrm{~Hz}, 1 \mathrm{H}) 7.20(\mathrm{q}$, $J=4.7,2.9,4.8 \mathrm{~Hz}, 1 \mathrm{H}) 7.29(\mathrm{dd}, J=1.8,4.6,1.8 \mathrm{~Hz}$, 1H) $7.36-7.42(\mathrm{~m}, 1 \mathrm{H}) 7.57(\mathrm{~d}, J=8.6 \mathrm{~Hz}, 1 \mathrm{H}) 8.53(\mathrm{~d}$, $J=5.8 \mathrm{~Hz}, 1 \mathrm{H}) ;{ }^{13} \mathrm{C}$ NMR $\left(62.90 \mathrm{MHz}, \mathrm{CDCl}_{3}\right): \delta=19.39$, $55.87,111.24,121.20,122.61,125.30,129.91,130.93,137.8$, 145.94, 147.02 (Lit. [28]).

2-(1-Naphthyl)phenyl diethylcarbamate (29) was prepared in a similar way as 25 . Yield $483 \mathrm{mg}(74 \%) ;{ }^{1} \mathrm{H}$ NMR 
$\left(300.33 \mathrm{MHz}, \mathrm{CDCl}_{3}\right): \delta=0.37-1.36(\mathrm{~m}, 6 \mathrm{H}) 2.62-3.54$ $(\mathrm{m}, 4 \mathrm{H}) 7.07-7.66(\mathrm{~m}, 9 \mathrm{H}) 7.85-7.89(\mathrm{~m}, 2 \mathrm{H}) ;{ }^{13} \mathrm{C}$ NMR $\left(62.90 \mathrm{MHz}, \mathrm{CDCl}_{3}\right): \delta=13.42,41.41,122.19,123.45$, $125.65,126.05,126.32,126.77,127.03,127.83,128.18$, $128.34,129.07,129.61,131.92,133.54,148.27,151.64$, 159.83; IR (neat) $v=3050,3000,1992,1892,1832,1587$, $1568,1505,1468,1433,1388,1254,1218,1197,1178,1133$, 1108, 1016, 971, 918, 873,788, 685, 657, 626, 572, 550, 443; HRMS (ESI): $\mathrm{m} / \mathrm{z}=220.1125\left[\mathrm{C}_{16} \mathrm{H}_{13} \mathrm{~N}+\mathrm{H}\right]^{+}, \mathrm{m} / \mathrm{z}$ (teor.) $=$ 220.1121, diff. $=1.82 \mathrm{ppm}$.

3-Methyl-2-(1-naphthyl)pyridine (31) was prepared in similar way as 25 . Yield $781 \mathrm{mg}(74 \%) ;{ }^{1} \mathrm{H}$ NMR $(300.33 \mathrm{MHz}$, $\left.\mathrm{CDCl}_{3}\right): \delta=2.11(\mathrm{sc}, 3 \mathrm{H}) 7.30(\mathrm{dd}, J=4.94,2.93,4.94 \mathrm{~Hz}$, $1 \mathrm{H}) 7.41-7.68(\mathrm{~m}, 4 \mathrm{H}) 7.59(\mathrm{t}, J=6.95,8.23 \mathrm{~Hz}, 1 \mathrm{H})$ $7.67(\mathrm{~d}, J=7.68 \mathrm{~Hz}, 1 \mathrm{H}) 7.93(\mathrm{~d}, J=8.23 \mathrm{~Hz}, 2 \mathrm{H}) 8.64$ $(\mathrm{d}, J=4.39 \mathrm{~Hz}, 1 \mathrm{H}) ;{ }^{13} \mathrm{C}$ NMR $\left(62.90 \mathrm{MHz}, \mathrm{CDCl}_{3}\right): \delta=$ $19.72,122.96,125.79,125.85,126.25,126.72,126.82,128.73$, $128.78,131.85,131.98,132.98,134.14,138.30,147.37$, 158.96; IR (neat) $v=3058,2973,2933,2874,1712,1592$, 1509, 1471, 1457, 1414, 1379, 1316, 1272, 1259, 1200, 1151, $1096,1045,956,937,802,778,751,618$. HRMS (ESI): $\mathrm{m} / \mathrm{z}=$ $320.1630\left[\mathrm{C}_{21} \mathrm{H}_{21} \mathrm{NO}_{2}+\mathrm{H}\right]^{+}, \mathrm{m} / \mathrm{z}$ (teor.) $=320.1645$, diff. $=$ $4.69 \mathrm{ppm}$.

Biphenyl-2,2'-diyl bis(diethylcarbamate) (34). A $100 \mathrm{~mL}$ flask equipped with a magnetic stirrer was charged with $2,2^{\prime}$ biphenol (33) (26.8 mmol, 1 equiv.), dimethylformamide $(30 \mathrm{~mL}), \mathrm{N}$-methylimidazole $(2.5 \mathrm{~mL})$, triethylamine $(5.4 \mathrm{~g}$, $53.7 \mathrm{mmol}, 2.2$ equiv.) and diethylcarbamoyl chloride (20) (7.3 g, 2.2 equiv.). The flask was closed with a tight PTFE stopper and heated at $100^{\circ} \mathrm{C}$ for $24 \mathrm{~h}$. After that time the reaction solution was cooled down to room temperature and the solvents were removed under reduced pressure. $100 \mathrm{~mL}$ water was added to a residue and the product was extracted with diethyl ether $(90 \mathrm{~mL})$, washed with water $(80 \mathrm{~mL})$, and $5 \%$ aq. $\mathrm{NaOH}(30 \mathrm{~mL})$. The organic phase was separated and dried with $\mathrm{MgSO}_{4}$. Solvent was evaporated in vacuum and the remaining residue was purified by column chromatography on silica gel using hexane/acetone (9/1) as an eluent. Yield $6.87 \mathrm{~g}(67 \%) .{ }^{1} \mathrm{H}$ NMR $(300.33 \mathrm{MHz}$, $\left.\mathrm{CDCl}_{3}\right): \delta=0.86-1.03(\mathrm{~m}, 12 \mathrm{H}) 3.11-3.21(\mathrm{~m}, 8 \mathrm{H})$ 7.18-7.38 (m, 8H). (Lit. [29]).

2'-hydroxybiphenyl-2-yl diethylcarbamate (35) was also obtained in this reaction leading to 34 in $0.79 \mathrm{~g}(10 \%)$ yield. ${ }^{1} \mathrm{H}$ NMR $\left(300.33 \mathrm{MHz}, \mathrm{CDCl}_{3}\right): \delta=0.92-1.04(\mathrm{~m}, 6 \mathrm{H})$ $3.18-3.23(\mathrm{~m}, 4 \mathrm{H}) 6.92-6.95(\mathrm{~m}, 1 \mathrm{H}) 6.98-7.01(\mathrm{~m}, 1 \mathrm{H})$ $7.12(\mathrm{dd}, J=2.20,6.22,1.28,1 \mathrm{H}), 7.22-7.29(\mathrm{~m}, 2 \mathrm{H}) 7.33$ $(\mathrm{d}, J=3.48 \mathrm{~Hz}, 1 \mathrm{H}) 7.35(\mathrm{sc}, 1 \mathrm{H}) 7.42-7.47(\mathrm{~m}, 1 \mathrm{H})$; IR (neat) $v=3260,3061,2976,2935,2875,2707,1683,1606$, $1573,1506,1483,1442,1426,1379,1364,1275,1197,1165$, $1118,1095,1047,1006,966,938,842,818,748,618,574$, 496, 432; HRMS (ESI): $\mathrm{m} / \mathrm{z}=308.1240\left[\mathrm{C}_{17} \mathrm{H}_{19} \mathrm{NO}_{3}+\mathrm{Na}\right]^{+}$, $\mathrm{m} / \mathrm{z}$ (teor.) $=308.1257$, diff. $=5.52 \mathrm{ppm}$.

2-Pivaloyloxy-2'-N,N-diethylcarbomoyloxybiphenyl (39). A $100 \mathrm{~mL}$ flask equipped with a magnetic stirrer charged with $0.3 \mathrm{~g} 2^{\prime}$-hydroxybiphenyl-2-yl diethylcarbamate (35)
(1 mmol, 1 equiv.), $1.8 \mathrm{~mL}$ dimethylformamide, $0.1 \mathrm{~mL}$ $\mathrm{N}$-methylimidazole, and $0.2 \mathrm{~mL}$ triethylamine $(5.4 \mathrm{~g}$, $53.7 \mathrm{mmol}, 2.2$ equiv.) was cooled down to $0^{\circ} \mathrm{C}$, and pivaloyl chloride (21) (126.7 mg, $1 \mathrm{mmol}, 1$ equiv.) was added. The content were stirred for $2 \mathrm{~h}$ at $0^{\circ} \mathrm{C}$. The mixture next was stirred for 2 hours at room temperature; the solvents were removed under reduced pressure and a residue was diluted with water. The product was extracted with diethyl ether and washed with aqueous $1 \mathrm{M} \mathrm{HCl}$. The organic phase was separated and dried with $\mathrm{MgSO}_{4}$. Solvent was evaporated in vacuum, and the remaining residue was purified by column chromatography on silica gel using hexane/acetone (99/1) as an eluent. Yield $318 \mathrm{mg}(82 \%) .{ }^{1} \mathrm{H}$ NMR $(300.33 \mathrm{MHz}$, $\left.\mathrm{CDCl}_{3}\right): \delta=0.87-1.03(\mathrm{~m}, 15 \mathrm{H}) 3.12-3.22(\mathrm{~m}, 4 \mathrm{H}) 7.08-$ $7.11(\mathrm{~m}, 1 \mathrm{H}) 7.19-7.40(\mathrm{~m}, 7 \mathrm{H})$. IR (neat) $v=2973,2933$, 2874, 1749, 1715, 1471, 1414, 1380, 1367, 1270, 1250, 1227, 1198, 1153, 1110, 1045, 1010, 959, 938, 897, 749. HRMS $(\mathrm{ESI}): \mathrm{m} / \mathrm{z}=392.1855\left[\mathrm{C}_{22} \mathrm{H}_{27} \mathrm{NO}_{4}+\mathrm{Na}\right]^{+}, \mathrm{m} / \mathrm{z}$ (teor.) $=$ 392.1832 , diff. $=5.86$ ppm. (Lit. [30]).

2-(2'-Methoxybiphenyl-2-yl)-4,4-dimethyl-4,5-dihydro-1,3-oxazole (42). A dried Schlenk equipped with a magnetic stirrer was argonated by vacuum/argon triple exchange and charged with the $1 \mathrm{M}$ THF solution of Grignard reagent 41 (3.4 mmol, 3 equiv.) then 2-(2-methoxyphenyl)-4,4dimethyl-4,5-dihydro-1,3-oxazole (8) (1.1 mmol, 1 equiv.) was added and the reaction mixture was heated overnight at $80^{\circ} \mathrm{C}$. The reaction was allowed to cool down to room temperature and it was quenched with saturated aqueous solution of $\mathrm{NH}_{4} \mathrm{Cl}(3 \mathrm{~mL})$. The solvents were removed under reduced pressure, $100 \mathrm{~mL}$ of water was added to a residue and products were extracted with diethyl ether. The organic phase was separated and dried with $\mathrm{MgSO}_{4}$. Solvent was evaporated in vacuum and the remaining residue was purified by column chromatography on silica gel using hexane/acetone (99/1) as an eluent. Yield $299 \mathrm{mg}$ (94\%) of product. ${ }^{1} \mathrm{H}$ NMR $\left(300.33 \mathrm{MHz}, \mathrm{CDCl}_{3}\right): \delta=1.27$ (sc, $6 \mathrm{H}), 3.75(\mathrm{sc}, 3 \mathrm{H}), 3.78(\mathrm{sc}, 2 \mathrm{H}), 6.89-6.92(\mathrm{~m}, 1 \mathrm{H}), 7.02(\mathrm{t}$, $J=7.50,7.50 \mathrm{~Hz}, 1 \mathrm{H}), 7.24-7.41(\mathrm{~m}, 4 \mathrm{H}), 7.47-7.52(\mathrm{~m}$, 1H), 7.85-7.88 (m, 1H). (Lit. [31]).

4-Methoxy-5'-methyl-1,1':2', $1^{\prime \prime}$-terphenyl (45), 4-methoxy-

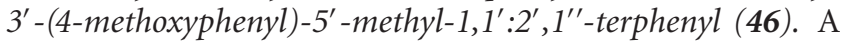
$50 \mathrm{~mL}$ flask equipped with a magnetic stirrer was argonated by vacuum/argon triple exchange and charged with $[\mathrm{RhCl}(\mathrm{cod})]_{2}(3 \mu \mathrm{mol}, 2.5 \mathrm{~mol} \%)$, tris(pentafluorophenyl) phosphine $(2 \%$-mol), and $2 \mathrm{~mL} N$-methylpyrrolidone (NMP). The reaction mixture stirred for 30 minute at $70^{\circ} \mathrm{C}$, cooled down to room temperature and to solution of formed catalyst 3-methyl-2-(4-methylphenyl)pyridine (25) (1.4 mmol, 1 equiv.), $p$-bromoanisole (44) $(2.8 \mathrm{mmol}$, 2 equiv.), $\mathrm{Cs}_{2} \mathrm{CO}_{3}$ (2.7 mmol, 2 equiv.) and $1 \mathrm{~mL} \mathrm{NMP} \mathrm{were}$ added. The solution was heated at $160^{\circ} \mathrm{C}$ for $24 \mathrm{~h}$, after that the reaction mixture was cooled down to room temperature. The products were extracted with diethyl ether and washed with water. The organic phase was separated and dried with $\mathrm{MgSO}_{4}$. Solvents were evaporated in vacuum, and the remaining residue was purified by column chromatography 
on silica gel using hexane/acetone (6/1) as an eluent to afford 45 (290 $\mathrm{mg}, 64 \%)$ and 46 (trace).

45: ${ }^{1} \mathrm{H}$ NMR $\left(300.33 \mathrm{MHz}, \mathrm{CDCl}_{3}\right): \delta=2.47(\mathrm{sc}$, $3 \mathrm{H}), 3.74(\mathrm{sc}, 6 \mathrm{H}), 6.66-6.69(\mathrm{~m}, 4 \mathrm{H}), 6.89-7.28$ $(\mathrm{m}, 9 \mathrm{H}), 8.29(\mathrm{~d}, J=4.76,1 \mathrm{H})$. IR (neat) $v=$ $3002,2953,2923,2858,2835,1608,1581,1568,1515$, 1496, $14601441,1423,1380,1290,1245,1177,1137$, 1111, 1066, 1051, 1031, 989, 827, 788, 597, 566, 520. HRMS (ESI): $\mathrm{m} / \mathrm{z}=290.1535\left[\mathrm{C}_{20} \mathrm{H}_{19} \mathrm{NO}+\mathrm{H}\right]^{+}, \mathrm{m} / \mathrm{z}$ (teor. $)=290.1539$, diff. $=1.38 \mathrm{ppm}$.

46: ${ }^{1} \mathrm{H}$ NMR $\left(300.33 \mathrm{MHz}, \mathrm{CDCl}_{3}\right): \delta=1.76(\mathrm{sc}, 3 \mathrm{H})$ $2.46(\mathrm{sc}, 3 \mathrm{H}) 3.76(\mathrm{sc}, 3 \mathrm{H}) 6.71(\mathrm{~d}, J=8.78,2 \mathrm{H})$ $7.04(\mathrm{~d}, J=8.78,2 \mathrm{H}) 7.08-7.12(\mathrm{~m}, 1 \mathrm{H}) 7.22-7.32$ $(\mathrm{m}, 5 \mathrm{H}) 8.50-8.52(\mathrm{~m}, 1 \mathrm{H})$. IR (neat) $v=2957$, 2928, 2835, 1710, 1607, 1576, 1510, 1460, 1441, 1421, $1401,1379,1290,1243,1176,1109,1031,830,793$, $731,595,568,548,530$. HRMS (ESI): $\mathrm{m} / \mathrm{z}=396.1958$ $\left[\mathrm{C}_{27} \mathrm{H}_{25} \mathrm{NO}_{2}+\mathrm{H}\right]^{+}, \mathrm{m} / \mathrm{z}$ (teor.) $=396.1958$, diff. $=$ $0.00 \mathrm{ppm}$.

\section{References}

[1] G. Bringmann, A. J. P. Mortimer, P. A. Keller, M. J. Gresser, J. Garner, and M. Breuning, "Atroposelective synthesis of axially chiral biaryl compounds," Angewandte Chemie-International Edition, vol. 44, no. 34, pp. 5384-5427, 2005.

[2] S. I. Gorelsky, D. Lapointe, and K. Fagnou, "Analysis of the concerted metalation-deprotonation mechanism in palladium-catalyzed direct arylation across a broad range of aromatic substrates," Journal of the American Chemical Society, vol. 130, no. 33, pp. 10848-10849, 2008.

[3] L. C. Campeau and K. Fagnou, "Applications of and alternatives to $\pi$-electron-deficient azine organometallics in metal catalyzed cross-coupling reactions," Chemical Society Reviews, vol. 36, no. 7, pp. 1058-1068, 2007.

[4] N. Miyaura, T. Yanagi, and A. Suzuki, "The palladiumcatalyzed cross-coupling reaction of phenylboronic acid with haloarenes in the presence of bases," Synthetic Communications, vol. 11, no. 7, pp. 513-519, 1981.

[5] S. Vyskočil, S. C. Lockhart, W. L. Mitchell, and P. Kočovský, "Synthesis of 2-hydroxy-8'-(hydroxymethyl)-1,1' binaphthalene (iso-homo-binol). A new structural pattern in the binaphthyl realm," Collection of Czechoslovak Chemical Communications, vol. 68, no. 5, pp. 907-916, 2003.

[6] M. J. Sharp, W. Cheng, and V. Snieckus, "Synthetic connections to the aromatic directed metalation reaction. Functionalized aryl boronic acids by ipso borodesilylation. General syntheses of unsymmetrical biphenyls and m-terphenyls," Tetrahedron Letters, vol. 28, no. 43, pp. 5093-5096, 1987.

[7] P. Knochel, "A new approach to boron-stabilized organometallics," Journal of the American Chemical Society, vol. 112, no. 20, pp. 7431-7433, 1990.

[8] T. Ishiyama, M. Murata, and N. Miyaura, "Palladium(0)catalyzed cross-coupling reaction of alkoxydiboron with haloarenes: a direct procedure for arylboronic esters," The Journal of Organic Chemistry, vol. 60, no. 23, pp. 7508-7510, 1995.

[9] T. Ishiyama, J. Takagi, K. Ishida, N. Miyaura, N. R. Anastasi, and J. F. Hartwig, "Mild iridium-catalyzed borylation of arenes. High turnover numbers, room temperature reactions, and isolation of a potential intermediate," Journal of the American Chemical Society, vol. 124, no. 3, pp. 390-391, 2002.

[10] S. Morandi, E. Caselli, A. Forni, M. Bucciarelli, G. Torre, and F. Prati, "Enantiomeric excess of 1,2-diols by formation of cyclic boronates: an improved method," Tetrahedron Asymmetry, vol. 16, no. 17, pp. 2918-2926, 2005.

[11] H. H. Hodgson, "The Sandmeyer reaction," Chemical Reviews, vol. 40, no. 2, pp. 251-277, 1947.

[12] R. P. Mariella and V. Kvinge, "Condensations of unsymmetrical ketones. II. Competition between methylene groups," Journal of the American Chemical Society, vol. 70, no. 9, pp. 3126-3128, 1948.

[13] O. M. Demchuk, K. Kielar, and K. M. Pietrusiewicz, "Rational design of novel ligands for environmentally benign crosscoupling reactions," Pure and Applied Chemistry, vol. 83, no. 3, pp. 633-644, 2011.

[14] A. I. Meyers, R. Gabel, and E. D. Mihelich, "Nucleophilic aromatic substitution on o-(methoxy)aryloxazolines. A convenient synthesis of o-alkyl-, o-alkylidene-, and o-arylbenzoic acids," Journal of Organic Chemistry, vol. 43, no. 7, pp. 13721379, 1978.

[15] T. Hattori, J. Sakamoto, N. Hayashizaka, and S. Miyano, "Nucleophilic aromatic substitution reactions of 1-methoxy2- (diphenylphosphinyl)naphthalene with $\mathrm{C}-, \mathrm{N}-$, and $\mathrm{O}-$ nucleophiles: facile synthesis of diphenyl(1-substituted-2naphthyl)phosphines," Synthesis, vol. 1994, no. 2, pp. 199-202, 1994.

[16] O. Demchuk and E. Łastawiecka, "Direct arylation via C-H Bonds activation," Wiadomości Chemiczne, vol. 64, no. 7-8, pp. 559-597, 2010.

[17] L. C. Campeau, D. R. Stuart, and K. Fagnou, "Recent advances in intermolecular direct arylation reactions," Aldrichimica Acta, vol. 40, no. 2, pp. 35-41, 2007.

[18] D. Qu, Q. Wang, J. Ren, and H. Tian, "A light-driven rotaxane moleculer shuttle with dual fluorescence addresses," Organic Letters, vol. 6, p. 2085, 2004.

[19] M. B. Faraoni, L. C. Koll, S. D. Mandolesi, A. E. Zuniga, and J. C. Podesta, "Transmetallations between aryltrialkyltins and borane: synthesis of arylboronic acids and organotin hydrides," Journal of Organometallic Chemistry, vol. 613, pp. 236-238, 2000.

[20] W. Köenig and W. Scharrnbeck, "Beiträge Zur Kenntnis der aromatischen Borverbindungen und der aus diesen gewinnbaren Arylquecksilbersalze," Journal für Praktische Chemie, vol. 128, no. 1, pp. 153-170, 1930.

[21] D. L. Yabroff, G. E. K. Branch, and B. Bettman, "The relative strengths of some hydrocarbon derivatives of boric acid," Journal of the American Chemical Society, vol. 56, no. 9, pp. 1850-1857, 1934.

[22] K. J. Singh and D. B. Collum, "Lithium diisopropylamidemediated ortholithiation and anionic fries rearrangement of aryl carbamates: role of aggregates and mixed aggregates," Journal of the American Chemical Society, vol. 128, no. 42, pp. 13753-13760, 2006.

[23] F. Ameer, I. R. Green, K. Krohn, and M. Sitoza, "Strategies towards the synthesis of 6-N,N-diethylcarbamyloxy-1,4dimethoxy- 7-naphthylboronic acid," Synthetic Communications, vol. 37, no. 18, pp. 3041-3057, 2007.

[24] D. Qiu, F. Mo, Z. Zheng, Y. Zhang, and J. Wang, "Gold(III)catalyzed halogenation of aromatic boronates with $\mathrm{N}$ halosuccinimides," Organic Letters, vol. 12, no. 14, p. 5474, 2010.

[25] J. J. Mousseau, F. Vallée, M. M. Lorion, and A. B. Charette, "Umpolung direct arylation reactions: facile process requiring 
only catalytic palladium and substoichiometric amount of silver salts," Journal of the American Chemical Society, vol. 132, no. 41, pp. 14412-14414, 2010.

[26] Z. Zhao and V. Snieckus, "Directed ortho metalationbased methodology. Halo-, nitroso-, and boro-induced ipsodesilylation. Link to an in situ Suzuki reaction," Organic Letters, vol. 7, no. 13, pp. 2523-2526, 2005.

[27] S. Jung, Y. Kang, H. S. Kim et al., "Effect of substitution of methyl groups on the luminescence performance of $\operatorname{Ir}^{I I I}$ complexes: preparation, structures, electrochemistry, photophysical properties and their applications in Organic LightEmitting Diodes (OLEDs)," European Journal of Inorganic Chemistry, vol. 2004, no. 17, pp. 3415-3423, 2004.

[28] M. J. Bishop, K. A. Barvian, J. Berman et al., " $\alpha_{1}$-Adrenoceptor agonists: the identification of novel $\alpha_{1 A}$ subtype selective $2^{\prime}$ heteroaryl-2-(phenoxymethyl)imidazolines," Bioorganic and Medicinal Chemistry Letters, vol. 12, no. 3, pp. 471-475, 2002.

[29] N. Thasana, S. Pisutjaroenpong, and S. Ruchirawat, "Two protocols for the conversion of biphenol to binaphthol: synthesis of diospyrol," Synlett, vol. 7, pp. 1080-1084, 2006.

[30] A. I. Meyers and P. D. Pansegrau, "The synthesis of 1,2,3trisubstituted benzenes. Further comments on benzynes derived from aryl oxazolines," Tetrahedron Letters, vol. 24, no. 45, pp. 4935-4938, 1983.

[31] C. R. Ellefson, K. A. Prodan, L. R. Brougham, and A. Miller, "Synthesis of 8-aryltetrahydroisoquinolines as dopamine antagonists and evaluation for potential neuroleptic activity," Journal of Medicinal Chemistry, vol. 23, no. 9, pp. 977-980, 1980. 


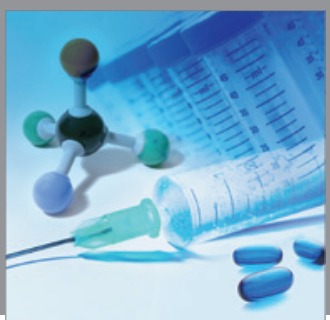

International Journal of

Medicinal Chemistry

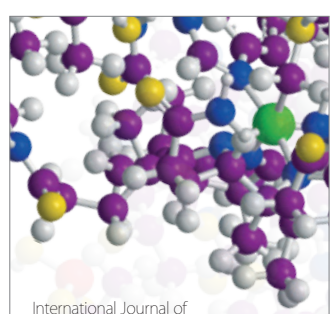

Carbohydrate Chemistry

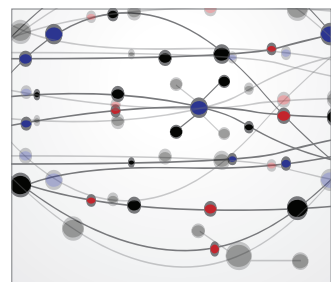

The Scientific World Journal
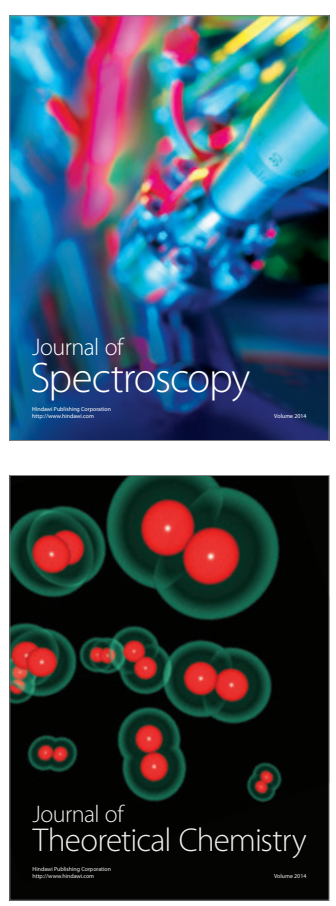
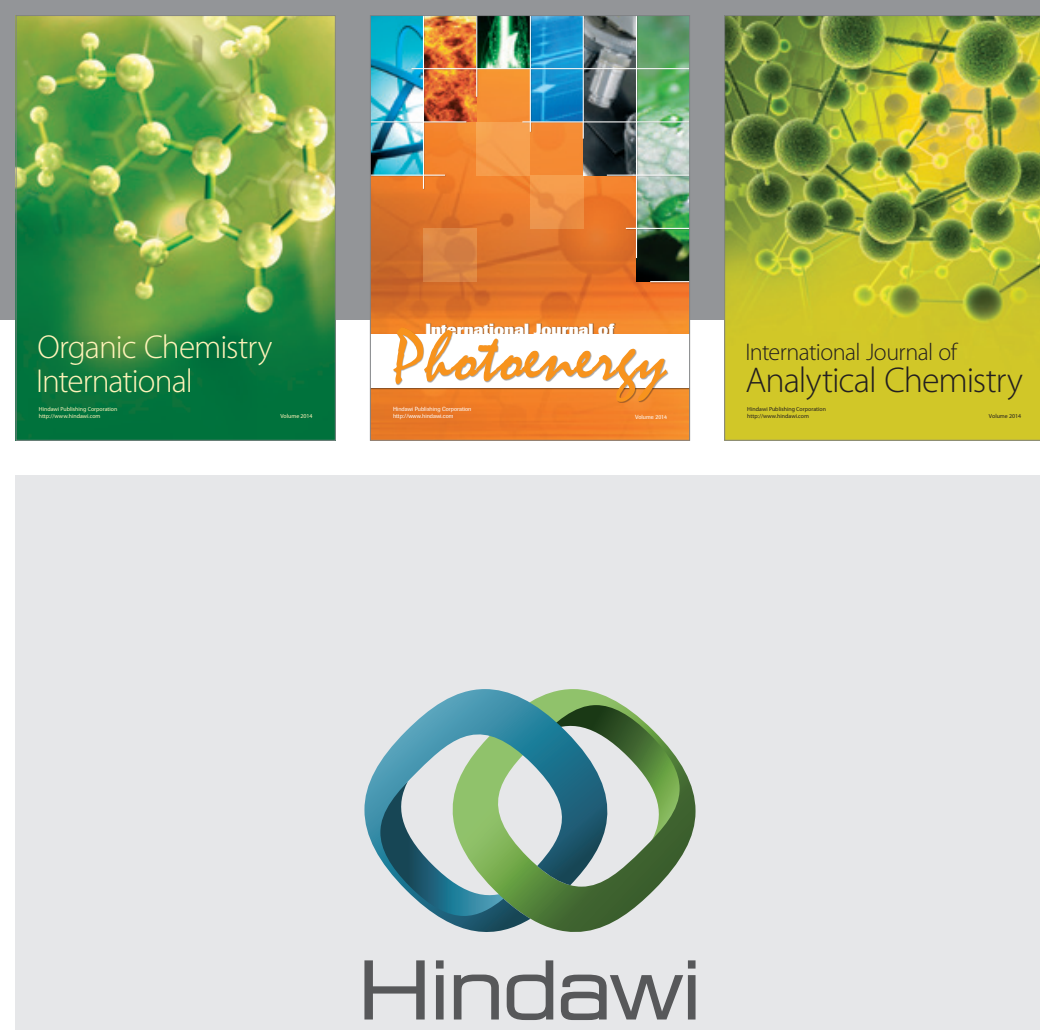

Submit your manuscripts at

http://www.hindawi.com
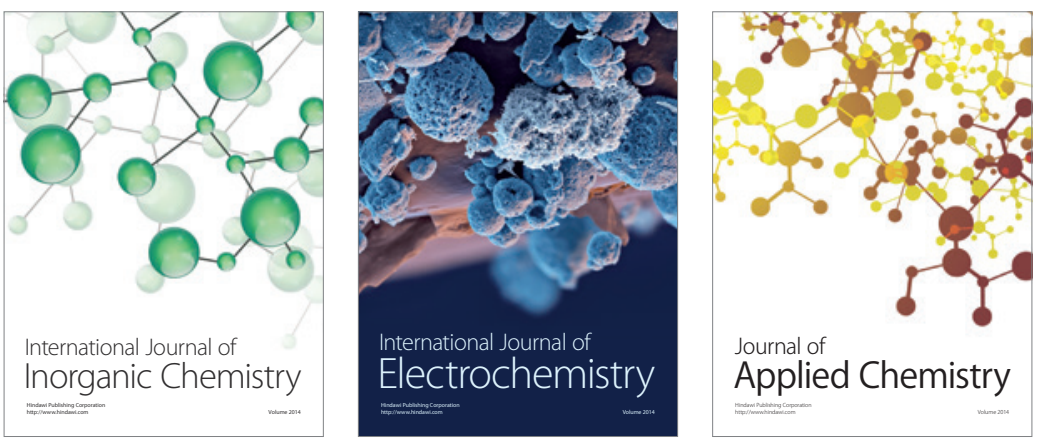

Journal of

Applied Chemistry
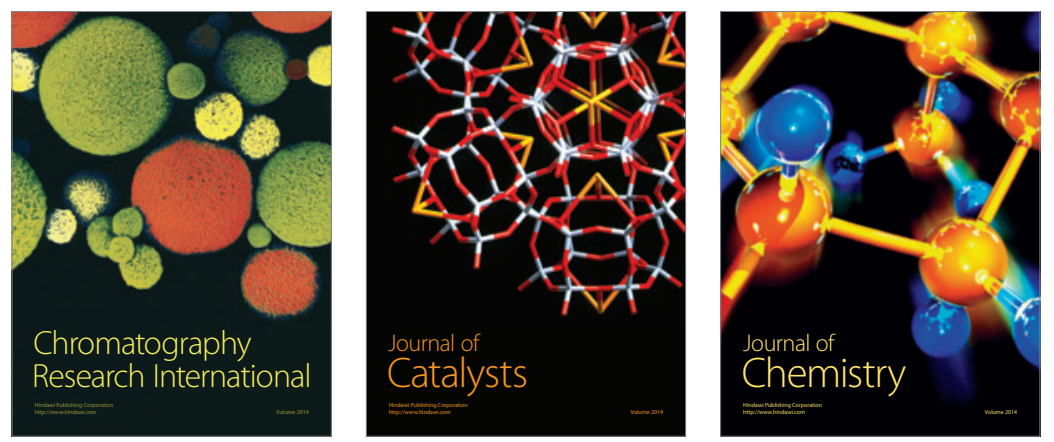
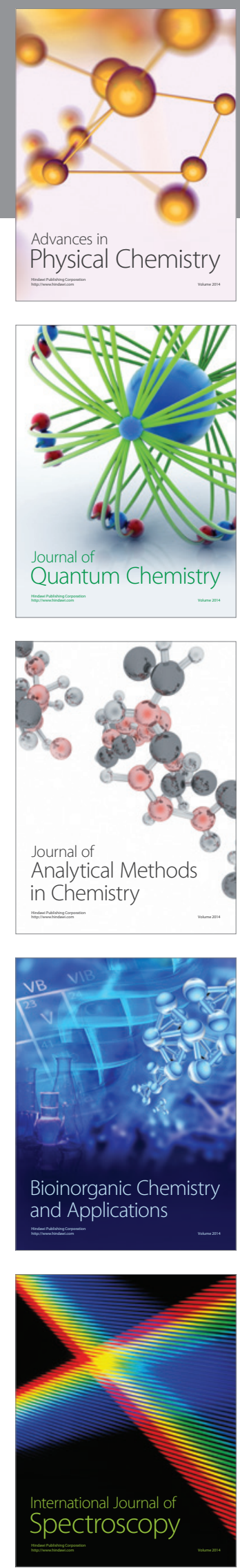